\title{
Portuguese as an Additional Language within the context of Exchange Programme for Undergraduate Students: a proposal for theoretical and pedagogical shift
}

\author{
Michele Saraiva Carilo ${ }^{1}$ \\ The Ohio State University - OSU, Columbus, Ohio, EUA
}

\begin{abstract}
This article investigates the processes of curriculum development and enactment for Portuguese as an Additional Language (PAL) courses within the context of Exchange Programme for Undergraduate Students (PEC-G). Nine PAL programme co-ordinators and ten PAL instructors participated in personalised in-depth semi-structured interviews which were guided by the research question: what shapes curriculum within the context of PAL for PEC-G? The findings revealed that the examination for the Certificate of Proficiency in Brazilian Portuguese (Celpe-Bras) had been serving as guidelines for curriculum development and/or enactment within the context of PAL for PEC-G students. While critically acknowledging the contributions of communicative-driven and task-based approaches to the additional language education field, critical and intercultural pedagogies are introduced as an alternative for a theoretical and pedagogical shift within the PAL field - especially for the purposes of curriculum development and enactment.
\end{abstract}

Keywords: Portuguese as an Additional Language; Certificate of Proficiency in Brazilian Portuguese; Curriculum development and enactment; Critical and intercultural pedagogies.

Título: Português como Língua Adicional no contexto do Programa de Estudante-Convênio de Graduação: uma proposta de atualização teórico-pedagógica

Resumo: $O$ presente artigo apresenta um estudo sobre os processos de desenvolvimento e implementação curriculares para cursos de Português como Língua Adicional (PLA) no contexto do Programa de Estudante-Convênio de Graduação (PEC-G). A partir da questão norteadora: o que formata currículos de PLA no contexto do PEC-G? e com base na vertente construtivista da Teoria Fundamentada nos Dados, nove coordenadores e dez professores de programas de PLA - representando sete universidades federais - participaram de entrevistas em profundidade semiestruturadas. Os resultados revelaram que o exame do Certificado de Proficiência em Língua Portuguesa para Estrangeiros (Celpe-Bras) serve como orientação para desenvolvimento e/ou implementação curricular para cursos de PLA no contexto do PEC-G. Enquanto as contribuições das abordagens comunicativas e baseadas em tarefas para a área da educação de línguas adicionais são reconhecidas, pedagogias críticas e interculturais são introduzidas para propor uma atualização teóricopedagógica no campo do PLA - especialmente para desenvolvimento e implementação curriculares.

\footnotetext{
${ }^{1}$ Doutora em Educação de Línguas Modernas pela University of Edinburgh (UoE). Professora de Português como Língua Adicional e Coordenadora do Programa de Língua Portuguesa na Ohio State University (OSU). Orcid: https://orcid.org/0000-0002-2888-1415. E-mail: saraivacarilo.1@osu.edu
} 
Palavras-chave: Português como Língua Adicional; Certificado de Proficiência em Língua Portuguesa para Estrangeiros; Desenvolvimento e implementação curricular; Pedagogias críticas e interculturais.

\section{Introduction}

The curriculum development and enactment processes for additional language education tend to be influenced by several external factors, such as societal demands, language-in-education policies informed by work market, proficiency examinations, and textbooks (GRAY, 2010). Theoretical, political, and ideological perspectives which contribute to conceptualisations of language, language use, competence, and culture also play an important and influential role in curriculum development for additional languages and, therefore, in pedagogical practices (NATION; MACALISTER, 2010). Additional language education should aim to provide teaching and learning experiences that go beyond the memorisation of and/or ability to mimic language skills which can be objectively measurable and straightforwardly transferable across communicative tasks (KRAMSCH, 2009). Nevertheless, within the Portuguese as an Additional Language (PAL) field, the examination for the Certificate of Proficiency in Brazilian Portuguese (Celpe-Bras), as a political instrument, both establishes and advances language skills which should be socially, culturally, and/or economically aspired.

Considering that the Celpe-Bras examination is informed by Communicative Language Teaching (CLT) and Task-Based Language Teaching (TBLT) approaches, it can be argued that these theoretical and pedagogical perspectives also serve as guidelines for the PAL education in general - especially for the purposes of curriculum development and enactment. Despite acknowledging the importance of the Celpe-Bras examination in certifying proficiency in Brazilian PAL and in representing the only official language policy for PAL education in Brazil, theoretical constructs on which Celpe-Bras is based - CLT and TBLT - are obsolete for pedagogical purposes, given that such theories echo essentialist views of language, culture, and nation. Hence, this article presents a study from which a proposal for a theoretical and pedagogical shift for PAL education emerged.

The first part of this article comprises of three sections in which literature on curriculum development and enactment, communicative approaches within PAL education, and critical intercultural language pedagogies are reviewed in order to provide an overview of the theoretical basis and relevant, both traditional and current, perspectives on additional language education. Curriculum development is addressed in terms of participation and representation, or lack thereof, of agents who are directly and/or indirectly involved in the teaching and learning processes. Due to underrepresentation and/or lack of participation of teachers and students, at least two curricula can be developed: (1) intended, planned, or official curriculum, which usually reflects decisionmakers' viewpoints; and (2) operational, received, or actual curriculum, which is flexible and often a work in progress within the classroom itself. Then, key elements, procedures, and analysis which must be considered for the design of additional language curriculum are discussed. External elements that might 
influence syllabus design for additional language education, especially proficiency examinations and textbooks, are analysed in order to justify certain pedagogical choices.

This article discusses theoretical perspectives related to CLT and TBLT on which pedagogical assumptions for PAL education have been based, offering a critical review regarding notions of language, language use, competence, and culture. The influence of such concepts on the Celpe-Bras examination, and, consequently, the impact of Celpe-Bras on PAL education itself, is forwarded to address how those notions are reflected in the examination. Given the limitations of CLT and TBLT concerning notions of language, culture, and competence, additional language education is introduced under critical and intercultural lenses for the purpose of (re)conceptualising language, language use, competence, and culture. This (re)conceptualisation involves several changes; thus, implications for curriculum, syllabus, materials, and assessment are discussed.

The second part of this article focuses on the context of the research project - PAL for students participating in the Exchange Programme for Undergraduate Students (PEC-G). In so doing, it presents, in detail, the methodological procedures for data gathering and analysis informed by Constructive Grounded Theory (CGT) - which were utilised to develop such study. The third part presents the findings and the interpretations of these findings which shaped the development of the theory. The fourth part introduces the implications of a theoretical and pedagogical shift within PAL education for curriculum development and enactment especially for syllabus, materials, and assessment - as well as for teacher education programmes.

\section{Curriculum development and enactment for additional language education}

This section presents and discusses key elements for curriculum development and enactment. Firstly, it draws differences and similarities between intended/planned/official curriculum and operational/received/actual curriculum in order to determine whether those involved in both processes - development and enactment - participate in, contribute to, and/or are represented by the curriculum itself. Then, it reviews the principles of the model for curriculum design for additional language education of Nation and Macalister (2010) which, ideally, intertwine as a system to inform syllabus design. Finally, it weights advantages and disadvantages of the influence that textbooks (CANALE, 2016; FORMAN, 2014; GRAY, 2010) and proficiency examinations (KRAMSCH, 2005; SHOHAMY et al., 1996; SCHOFFEN, 2009) can have on curriculum.

The processes of curriculum development and enactment

The definition of curriculum, informing this article, comprises the broad idea of an educational plan, a pedagogical medium through which knowledge is reached by people, and a work in progress (BARNETT, 2000; MARSH, 2004). Curriculum here does not mean syllabus, since, in so doing, it limits curriculum to only one of its multiple dimensions: content. Barnett 
(2000) cogently argues that all the dimensions of a curriculum should be educationally justifiable and democratically problematised with the objective to build a plan and constantly review it rather than present a to-do list. In that sense, curriculum becomes a product of democratic debates around social changes.

Although transformational in nature, social and educational stakeholders play various roles during the processes of curriculum development and enactment; thus, a deeper discussion about the differences and similarities between what is planned and what is executed seems imperative. Eisner (1990) and Keller (2009) insightfully distinguish the intended/planned/official (IPO) curriculum from the operational/received/actual (ORA) curriculum. According to them, the IPO curriculum is a document - often conceived outside of the educational institution - whereas the ORA curriculum is the result of teachers' interpretation and mediation of the IPO curriculum - both inside and outside the classroom, with and without students' participation and/or contribution. Contextualisation, according to classroom's realities or critical disagreement towards what is pedagogically proposed by IPO curriculum, can consciously or unconsciously inspire teachers' and/or students' actions upon IPO curriculum, generating ORA curriculum.

Even though terms such as contextualisation and adjustment are often related to ORA curriculum, IPO curriculum is not conceived neutrally or within a social void. On the contrary, local, state, national, and/or global socioeconomic demands, political-ideological stances, and/or interests of dominant sectors of society can widely influence IPO curriculum. Apple (2008) accurately argues that educational institutions are potentially one of the major apparatus through which power can be either maintained or questioned. The rationale behind frameworks for the development of IPO curriculum, thus, enforces or challenges status quo implicitly or explicitly. Additionally, not including those involved in developing ORA curriculum in the decision-making processes related to IPO curriculum might broaden the gap between curriculum development and curriculum enactment.

Adopting a curriculum does not necessarily mean enacting it; moreover, curriculum enactment does not represent a linear transfer from IPO curriculum to the classroom especially when teachers need to learn IPO curriculum for not having been included in the development processes. While lack of commitment towards IPO curriculum can affect enactment negatively, it can also strengthen development and enactment of ORA curriculum (BASCIA et al., 2014; FULLAN, 2008). According to Gandana and Parr (2013), since teachers play a critical role in curriculum enactment, decisions within their daily practice are connected to their sociocultural backgrounds and current realities. Alongside teachers' voices, students' perspectives also contribute to curriculum (re)interpretation. In other words, teachers interpret and rewrite IPO curriculum into ORA curriculum; however, ORA curriculum cannot be expected to become the final version - otherwise, teachers would be treating students as IPO curriculum developers treat teachers.

\section{The additional language curriculum}


Just as any curriculum, an additional language curriculum tends to address what knowledge, skills, and values should be taught and learned, what experiences should be prioritised, and how teaching and learning processes should be managed. In order to dimin ish the gap between IPO curriculum and ORA curriculum, Nation and Macalister (2010) suggest that curriculum design should be seen as a type of writing, analysed as processes and subprocesses within which various sets of intertwined elements should be considered equally, and, therefore, propose the following model.

Figure 1 - Model for Additional Language Curriculum Design

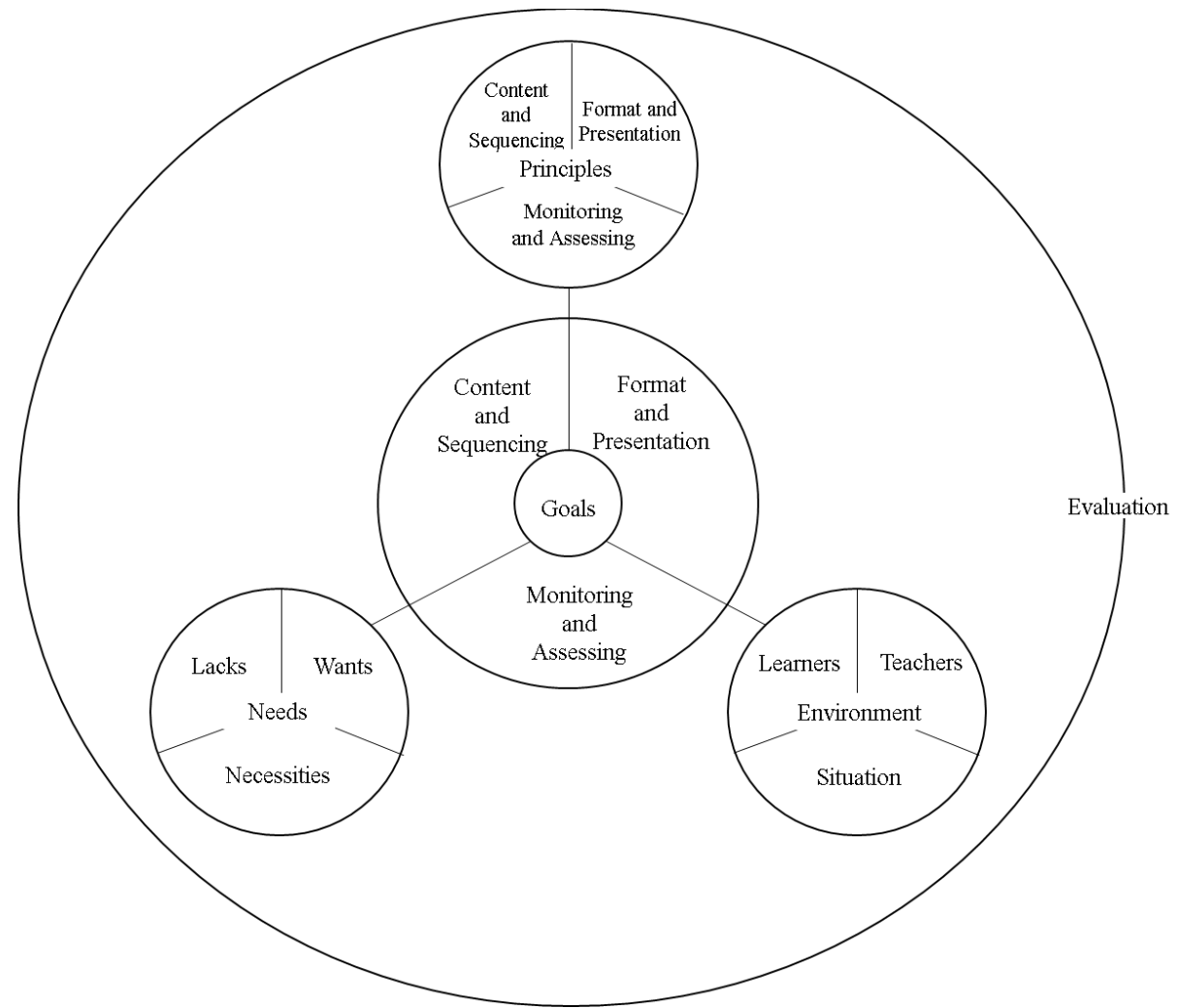

Source: Carilo (2018) adapted from Nation and Macalister (2010).

The model presents syllabus in the inner circle with goals in the centre to signal the importance of reflecting upon and establishing general, yet clear, pedagogical goals based on contextual needs. Those goals are interrelated to the following processes: content and sequencing, format and presentation, and monitoring and assessing. Such processes, in turn, are connected to the outer circles, or curriculum itself, and the principles circle - strategically positioned within the model to be informed by the environment and the needs circles. Finally, as a writing exercise, evaluation, or rewriting, encapsulates all the circles to represent the work-in-progress aspect of curriculum design.

Richards (2017) expands on the importance of considering contextual needs as curriculum development and enactment for additional language courses become a comprehensive process during which developer(s) must (1) determine individual and communal needs; (2) develop pedagogical goals to address those needs; (3) design appropriate syllabus; (4) establish course structure and teaching methods; and (5) carry out 
constant evaluation of the entire process. Focusing on syllabus design, Mickan (2013) defines such element as an outline of practical, realistic, and well-specified aims, objectives, and outcomes. Often, performance, in order to achieve real-life like interactions, is prioritised and set out to be the only goal of an additional language curriculum and, consequently, the organising principle around which syllabus is designed and on which teaching and learning rely. With that in mind, external products, such as published instructional materials and proficiency examinations, offer predetermined programmes upon which additional language syllabi can be built.

\section{External influences within the process of additional language syllabus design}

Although additional language textbooks might aim to provide structured information regarding language and cultural content, those instructional materials are extremely important for the promotion and teachability of additional languages worldwide. Nevertheless, when the authority of those materials remains unchallenged - due to, for example, publishers' and/or authors' reputation, this single-voiced influence can be more harmful than positive to additional language education. For Canale (2016) and Forman (2014), accepting textbooks' table of contents as syllabus and linguistic and sociocultural depictions as accurate representations might contribute to (1) standardisation rather than contextualisation of what to teach/learn and how; and (2) promoting unilateral ideologies and stereotypes. Furthermore, Gray (2010) attributes to additional language textbooks the characteristic of a learning/teaching tool which, when unproblematised, might help the advancement of particular discourses and selected voices to specific audiences.

In that sense, linguistic, sociocultural, and ideological diversity might be purposefully silenced to satisfy and/or meet expectations of whom consumes those materials while controlling representation. Kramsch (2014) defines this practice as an attempt to transform language and additional language teaching materials into commodities; that is, a sort of travelling agency brochure in which diversity might be presented without, however, encouraging people to engage with differences. By selling cultural and linguistic homogenisation, certain social groups are granted linguistic and cultural ownership, and, consequently, are portrayed in textbooks as the norm whose abilities and levels of proficiency shall be echoed by additional language learners.

Standard proficiency examinations, that require knowledge and skills specifically related to purposes and/or levels at which they are aimed, can officially measure language proficiency. Additional language proficiency examinations are usually developed around communicative tasks which are claimed to simulate real-life interactions; however, measurement of specific knowledge prioritises, consciously or unconsciously, certain skills that can be identifiable and transferable across different communicative tasks while deeming other skills as irrelevant - such as the ability to convey interculturality within and across language communities (KRAMSCH, 2005). An additional language proficiency examination can influence syllabus design by advancing learning and teaching experiences which facilitate the 
development of knowledge that is measurable by the examination itself. This impact that proficiency examinations might have on additional language teaching and learning, especially on syllabus and material design, is referred to as the washback effect (SHOHAMY et al., 1996).

It is relevant to highlight that the washback effect can be either positive or negative. For Schoffen (2009), for example, a proficiency examination can positively guide syllabus goals whilst removing obsolete pedagogies and/or teaching approaches. Nevertheless, when a specific proficiency examination informs guidelines on teaching goals and learning outcomes, important elements that comprise a wholly understanding of an additional language might be erased from the teaching-learning process for being perceived as irrelevant for the examination, such as language varieties and sociocultural diversity. In other words, syllabus design that focuses on the preparation for a proficiency examination tends to limit additional language learners to the role of examinees.

\section{Communicative- and task-based perspectives applied to Portuguese as an Additional Language education}

For the purposes of this article, it is imperative to review the influence of communicative- and task-based approaches on Portuguese as an Additional Language (PAL). In so doing, this section discusses notions of language, competence, and culture - according to Communicative Language Teaching (CLT) and Task-Based Language Teaching (TBLT) perspectives - in terms of their representation within the additional language field (CANALE; SWAIN, 1980; NUNAN, 1991; NUNAN, 2004). Then, this section presents the specificities of the Certificate of Proficiency in Brazilian Portuguese (Celpe-Bras) in order to determine the extent to which Celpe-Bras impacts PAL education (SCARAMUCCI, 2004; 2012; SCHLATTER et al., 2009).

Overview of Communicative Language Teaching and Task-Based Language Teaching theoretical and pedagogical assumptions

CLT and TBLT are approaches on which important theoretical and pedagogical decisions have been based in order to provide policymakers, educators, and/or practitioners in the additional language education field with guidelines for curriculum development, syllabus and material design, and best practices. The notions of language, competence, and culture which have been promoted by such approaches must be highlighted for their contribution to the development of the Celpe-Bras examination and, consequently, PAL education.

By rejecting descriptions of language as system, Halliday (1973) defines language as a means through which one can function ideationally, interpersonally, and textually within society while interplaying meaning making and communication. Halliday's assumption echoes the definition of communicative competence of Hymes (1972) - which comprises grammatical knowledge and ability for language use. Building upon Halliday's and Hymes' notions of 
language and competence, respectively, Canale and Swain (1980) and Canale (1983) propose a framework of language competence for pedagogical purposes - in which communicative competence is a combination of grammatical, sociolinguistic, discourse, and strategic competences. Thus, communicative competence interrelates various sociocultural factors which vary from culture to culture - that are identified and identifiable as basic rules for language use within a certain context in order to perform a communicative task.

For Nunan (1991; 2004), communicative tasks are opportunities of language use during interactions in a grammatically, contextually, socially, and culturally appropriate manner. Encapsulating this idea of appropriateness, the notion of authenticity is foregrounded in terms of authentic language and authentic materials. Authenticity, within the CLT and TBLT approaches, is defined as any sort of text - oral or written - which is not aimed at language teaching (CANALE; SWAIN, 1980; NUNAN, 2004) and language production/comprehension resulting from in-class communicative tasks (BREEN, 1989). In this sense, the scope of authenticity is both endless, since it comprises any text for non-pedagogical purposes and any interpretation of those texts that originates in educational settings, and limiting, for it disregards students' experience with additional languages outside the classroom.

Kachru (2006) insightfully points out how notions of authenticity and culture are intertwined within CLT and TBLT approaches when questioning who produces those authentic texts as well as to whom they are produced. Authentic texts that are incorporated in textbooks and/or tailored materials frequently belong to dominant classes and, because of that, are granted the status of the language and the culture rather than one language variety and one set of cultural representations amongst many others. By conferring authority to certain native speakers, linguistic and cultural ownership is limited; moreover, standardisation to promote a sense of homogenisation contributes to the one-country-one-language-one-culture essentialism. In summary, within CLT and TBLT, language proficiency can be measured through tasks that require the use of identifiable and transferable skills, during which communicative competence is granted if native-like performance is successfully emulated.

\section{The Certificate of Proficiency in Brazilian Portuguese (Celpe-Bras)}

The Celpe-Bras examination is divided into communicative tasks - representing an invitation for interactional engagement - which measure examinees' competence to use language in a socially and linguistically adequate manner (SCARAMUCCI, 1995; SCARAMUCCI, 2012). To be socially adequate, examinees are expected to use language as a contextually organised social action for communicative purposes aiming to demonstrate that they know what to say, to whom, when, and how (SCARAMUCCI, 1995; SCARAMUCCI, 2012). To be linguistically adequate, examinees' performance should demonstrate (1) language competence, or knowledge of linguistic components; (2) strategic competence, or mental capacity for implementing language competence to achieve contextualised language use; and (3) psychological mechanisms, or neuro-psychological processes through which language, as a physical phenomenon, can occur (SCARAMUCCI, 2000). 
Culture, in the Celpe-Bras examination, is an element of language within social adequacy, which means, non-native speakers acquire new cultural patterns that are specifically related to the target language native speakers. A study conducted by Lima (2008) reports that cultural representations of Brazil in Celpe-Bras examinations tend to promote urban- and cosmopolitan-based language varieties and cultures. Furthermore, culture is perceived to be homogenised and fully connected to the notion of nationality, since examinees are constantly requested to compare "the Brazilian culture" with "the culture of their own countries". The prioritisation of certain cultural aspects and language varieties, it can be argued, is part of an agenda for the internationalisation of a specific image of Brazil and the Brazilian Portuguese.

Celpe-Bras, as every proficiency certificate, represents, above all, a language and political instrument and, as such, can be used by governmental agencies to manage and promote how the Brazilian Portuguese circulates internationally. Zoppi-Fontana and Diniz (2008) justifiably expand on that concept by stating that Celpe-Bras is an instrument for language policy and for official institutional assessment. Such nature contributes to the washback effect that Celpe-Bras has over PAL education and the notions of language, competence, and culture which both inform and are promoted by the examination itself. Schlatter et al. (2009) argue that Celpe-Bras contributes to, rather than influences, PAL education by changing teachers' and students' perspectives regarding teaching, learning, and, especially, assessment. Scaramucci (2012), in turn, advocates for Celpe-Bras to influence fully PAL education - especially teacher development. Considering that the theoretical assumptions informing Celpe-Bras align to communicative- and task-based pedagogical practices, CLT and TBLT dominate PAL education - especially, the processes of curriculum development, curriculum enactment, syllabus and material design, and teaching and learning.

\section{Critical interculturality applied to additional language education}

Based on Freire's (1987) seminal work on critical education and his notion of conscientização, the theorisation of critical and intercultural pedagogies comprises groundbreaking ideas - such as the perspective of teaching as part of the learning process and viceversa in a dialectical and dialogical (re)production of socially and culturally diverse knowledges. In that sense, critical interculturality entails transformational engagement rather than simple participation and acknowledgement - of those involved in the teaching/learning process so that they can question, confront, and transform existing ways of perceiving and/or acting upon the world (LIDDICOAT; SCARINO, 2013). For speakers/users of an additional language, confrontation might occur when individuals engaging in an intercultural encounter cannot rely on their own behavioural patterns or set of values and beliefs for communication purposes. A new culture, an inter-culture, is, then, created collaboratively within and through the discourse to resolve such confrontation by transforming one's perspectives about one's own sociocultural stances and those of others. Ideally, by exercising critical interculturality, participants in an intercultural encounter 
conclude their interactions feeling understood, respected, and supported while providing their interlocutors with chances to feel the same.

When applied to additional language education, critical interculturality decentres whilst reconceptualising existentially, epistemologically, and sociologically - institutional and environmental foundations to provide equitability (GUILHERME; DIETZ, 2015). This pursuit of equitability should explicitly address and disturb relations of power within societal structures - including those within classrooms - by encouraging additional language students to become critical agents for intercultural citizenship. Guilherme (2012) accurately argues that language and culture are fundamental elements when transformational engagement is exercised through committed agency towards social justice - even if such commitment means to challenge one's own identity in terms of language, culture, and citizenship. Pedagogically speaking, critical intercultural pedagogies must consider sociocultural diverse representations, interpretations, expectations, memories, and identifications within the processes of teaching and learning the additional language. The following sections address the implications of applying critical intercultural pedagogies to additional language education.

\section{Implications for curriculum development and enactment}

Because critical and intercultural perspectives involve ideological and political engagement for emancipation and social justice, additional language students must be both seen as and encouraged to become sociocultural agents. In so doing, language teaching and learning must occur across and between the different cultures - informing and being informed by societal and individual experiences - on which those involved in the educational process can rely. Content, in turn, emerges from those experiences when they are represented, expressed, and shared through the target language while inter-cultures are (re)produced. Nevertheless, for additional language education to achieve those critical and intercultural goals, key elements - especially language, competence, and culture - need to be redefined; moreover, curriculum development and enactment must explicitly promote such redefinitions throughout.

The notion of language as a symbolic system, proposed by Kramsch (2011), thoroughly comprehends the critical and intercultural stance of those using language to apprehend oneself and others, one's world(s) and the world(s) of others. Thus, using an additional language means to expand the repertoire with which one can count to (re)signify one's own perspectives while taking into consideration viewpoints of others. The ability to use one or more symbolic systems enables individuals to develop declarative and performative symbolic power - which might contribute to the representation and creating, respectively, of multiple realities in multiple symbolic systems. These notions of language and language use, as symbolic system and symbolic power, challenge CLT- and TBLT-based additional language curriculum for promoting rather than erasing language varieties, for encouraging the use of multiple languages rather than pointing monolingual native speakers as models.

Communicative competence, which usually is measured via formative and/or 
summative assessment, is reconceptualised as symbolic competence which implies (re)framing perceptions of familiar and/or unfamiliar sociocultural contexts and realities in order to act upon them, change them, create alternatives for them rather than negotiating differences to achieve a sense of consensus (KRAMSCH, 2011). Critical intercultural additional language curriculum moves away from the ability to emulate idealised and unrealistic representations - such as that of a native speaker - and towards multilingual viewpoints that enable a multi-layered display of sociocultural and linguistic backgrounds which can influence the roles played during intercultural interactions. Thus, curriculum must connect the notion of competence to the capacity and/or potential to engage actively, critically, and interculturally in interactions in the target language.

Culture, under critical and intercultural lens, is a dynamic meaning-making process which depends on one's interpretations, perceptions, sociocultural backgrounds, historical stances, individual and communal identities rather than a set of characteristics intrinsically connecting people who share a nationality (HOLLIDAY, 2012). Curriculum must, then, promote multiple cultures - those related to identity elements that are decoupled from nationality, such as language, ethnicity, gender, race, religion, sexual orientation - to encourage additional language students to broaden their sociocultural and historical frameworks on which they rely to comprehend and interpret their own cultural stances and those of others.

In summary, critical- and intercultural-based additional language curriculum development and enactment must represent a flexible and easily contextualizable educational project which forwards democratic engagement towards social change through the use of multiple symbolic systems, by displaying symbolic competence, with the goal to expand cultural repertoire. In so doing, every element of the curriculum must reflect those goals especially syllabus, materials, and assessment instruments.

Implications for syllabus, materials, and assessment

For their concrete, official, and documented nature, syllabus, materials, and assessment are perfect representations of curriculum development and enactment on which theoretical perspectives and pedagogical goals might be more unmistakably identifiable. Nevertheless, identifiability does not necessarily mean that theoretical and pedagogical assumptions can be straightforwardly translated from the curriculum to the classroom. Conversely, Crozet (2017) justifiably argues that theoretical and pedagogical perspectives such as those promoted by critical and intercultural language pedagogies, do not offer a meticulous framework on which educators can rely to base their teaching strategies. In reality, critical intercultural language pedagogies provide decisionmakers, practitioners, and teachers with a set of paths around which personalised, rather than generalised, and contextualised, rather than standardised, guidelines can be built in order to inform syllabus, materials, and assessment. For Byram (2012), additional language teachers have the responsibility to facilitate the development of critical cultural awareness by promoting intercultural issues. If teachers, as earlier mentioned in this article, are rarely included in the processes of curriculum 
development, teachers can introduce, and then critically address, intercultural issues to the additional language classroom through the means of syllabus, material, and assessment instruments.

In terms of syllabus design, specifically, instead of focusing on grammatically based content with a communicative element, critical intercultural language pedagogies suggest language to be created and allowed to emerge from the social-, cultural-, political-, ideological-related issues being discussed. By accessing their own linguistic and cultural repertoire and social experiences, additional language students are able individually and collaboratively to recognise, (re)interpret, and (re)signify the familiar and the unfamiliar, the comfortable and the uncomfortable. In so doing, additional language-learning becomes a process during which human societies and cultures are studied and explored without the traditional, and possibly essentialised, association between native language/culture and target language/culture (KENNEDY et al., 2017). Additional language students, in turn, are educated to develop their sense of belonging in the world, to be multicultural/multilingual subjects, to act socially and critically with the purpose of questioning and problematising cultural differences across and within geographic borders.

For that sense of belonging to the world to be encouraged, materials must provide opportunities for the educating of both students and teachers politically - for additional language learning and teaching cannot be apolitical. Furthermore, identity-(re)building, through intellectual and emotional development, should be fostered to facilitate the dismantling of positive and negative cultural stereotypes and language standardisations on which, consciously or unconsciously, teachers and students might rely to avoid disrupting the status quo. According to Kennedy et al. (2017), when additional language students are allowed to invest emotionally, as well as intellectually, in their learning process, critical cultural awareness is developed and/or expanded through empathy towards moral dilemmas within their own cultures and those being studied.

Finally, promoting such kind of language learning without prioritising critical thinking and intercultural awareness in assessment criteria is an example of detachment between pedagogical goals and grading. Thus, communicative tasks focusing on linguistic and social adequacy do not reflect critical intercultural language pedagogies. Regardless of the instrument(s) through which assessment is conducted, criteria is key to foreground the use of language critically and interculturally. Analytical and emotional reflection on the materials, classroom discussions, linguistic and cultural experiences outside the classroom, and grammar content itself enables additional language students to establish ownership towards the studied language (KENNEDY et al., 2017). When diverse experiences - rather than native speakers' experiences - are presented to students and they recognise themselves and/or others in those experiences, language varieties substitute the homogenised target language, additional cultures replace the idealised single target culture, and multifaceted interpretations destabilise power relations.

The previous sections presented a review of relevant literature for the study reported in this article. The next sections introduce and discuss contextual, theoretical, and pedagogical 
specificities investigated and analysed for the development of this research project.

\section{Context of the study and methodological procedures}

This section provides an account of the context of this study and a justification for the methodological choices which guided its development. Firstly, the section generally introduces PAL within the context of Exchange Programme for Undergraduate Students (PECG) while presenting the specific investigated programmes. Then, it reports and discusses methods for data gathering and analysis under the lens of Constructivist Grounded Theory (CGT).

\section{Portuguese as an Additional Language within the context of PEC-G}

PEC-G was firstly offered in 1965 with the purpose of providing undergraduate studies in Brazilian higher education institutions to students from developing countries with which Brazil keeps educational, cultural, and/or scientific/technological agreements. Currently, 60 countries participate in PEC-G and the programme serves well internationalisation agendas within Brazilian higher education institutions. Amongst other requirements - related to age, nationality, educational background - being awarded a Celpe-Bras is mandatory for PEC-G students to be allowed to enrol in Brazilian universities; nonetheless, PEC-G students from countries where the Celpe-Bras examination is not applied, are offered PAL courses for near two academic semesters before taking the examination and receive the status of "pre-PEC-G" students. Although over 100 Brazilian universities participate in PEC-G, only twelve - in 2015, when this study was conducted - offered PAL courses to 182 pre-PEC-G students.

After having the seal of approval from the Ethics Committee at Moray House School of Education with the University of Edinburgh (under the reference number s1269836/2015), PAL programme co-ordinators or co-ordinating teams representing the twelve institutions were invited to participate in this study; however, representatives of seven Federal Universities (FU) agreed to be part of this research project and signed the consent forms. The consent forms were available both in English (official language of the Ethics Committee and University of Edinburgh) and in Portuguese (assumed native language of participants and official language within the FUs where the study took place). The table below summarises relevant information about those participants:

Table 1 - PAL Programme Co-ordinators Information

\begin{tabular}{|lll|}
\hline \multicolumn{1}{|c|}{ Pseudonym/FU } & \multicolumn{1}{c|}{ Tenure Rank } & \multicolumn{1}{c|}{ Research Background } \\
\hline Alice / FU01 & Retired Professor & Modern Languages, TESOL, Culture \\
Beatriz / FU01 & Professor & Portuguese, Linguistics \\
Cecília / FU01 & Staff Member & German, PAL, Human Rights \\
Denise / FU02 & Professor & French, PAL, Assessment \\
Elisa / FU03 & Professor & German, Translation Studies \\
\hline
\end{tabular}




\begin{tabular}{|lll|} 
Fernanda / FU04 & Professor & TESOL, PAL, Celpe-Bras \\
Gustavo / FU05 & Professor & PAL, Discourse Analysis, Project Pedagogy \\
Helena / FU06 & Teaching Fellow & Portuguese, PAL \\
Igor / FU07 & Professor & PAL, Language Policies, Assessment, Celpe-Bras \\
\hline
\end{tabular}

Source: adapted from Carilo (2018).

All participants had other responsibilities and institutional functions besides being PAL programme co-ordinators. These additional or main roles performed by those PAL programme co-ordinators are often related to teaching and, therefore, enable them to recruit their undergraduate and graduate students to become instructors within the PAL programmes. Due to their importance for the programmes, eleven PAL instructors representing those same seven FUs - agreed to participate in this study and signed the consent forms. The consent forms were available both in English (official language of the Ethics Committee and University of Edinburgh) and in Portuguese (assumed native language of participants and official language within the FUs where the study took place). The table below summarises their information:

Table 2 - PAL Programme Instructors Information

\begin{tabular}{|lll|}
\hline \multicolumn{1}{|c|}{ Pseudonym/FU } & Length of service & \multicolumn{1}{c|}{ Education / Research Background } \\
\hline Julia / FU01 & 20 years & Linguistics, PAL, Celpe-Bras, Language Policies \\
Laura / FU02 & 2 years & Literary Theory, French, PAL, Pedagogical Materials \\
Maria / FU02 & 2 years & Literary Theory, French, PAL, Assessment \\
Nair / FU02 & 4 years & Linguistics, French, PAL, Writing, Celpe-Bras, Culture \\
Olga / FU03 & 3 years & Linguistics, Literacy, Language Policies, Language Planning \\
Patricia / FU04 & 8 years & Applied Linguistics, PAL, Talk-in-interaction organisation \\
Quenia / FU05 & 3 years & History, Social Communication, Indigenous Languages, PAL \\
Regina / FU05 & 2 years & PAL, Cultural Production, Theatre \\
Silvia / FU06 & 10 years & Applied Linguistics, PAL, PAL in mainstream schools \\
Tereza / FU07 & 6 years & Linguistics, PAL, PAL for refugees \\
\hline
\end{tabular}

Source: adapted from Carilo (2018).

Similar to the co-ordinators, PAL instructors combined their teaching duties to other roles within the FUs and/or their own undergraduate/postgraduate studies; thus, teaching PAL to PEC-G students was one of their many responsibilities. The participation of PAL COordinators and instructors is detailed in the next section.

\section{Data gathering and data analysis}

Data gathering occurred through qualitative personalised in-depth semi-structured interviews. Qualitative interviews enable interpretation of interviewees' perspectives rather 
than a collection of indisputable facts (KVALE, 2007). Personalised interviews require the interviewer to study interviewees' biography beforehand to build a relevant set of topics from which questions might emerge (CHARMAZ, 2014). In-depth interviews allow for social and interpersonal interactions - which, ideally, create an experience during which interviewees feel comfortable with sharing their deepest understanding on the matter (JOHNSON, 2001). Semi-structured interviews, for permitting the interviewer to take an active stance and, therefore, to adjust the interview accordingly while it occurs, might picture, in detail, interviewees' beliefs, perceptions, and accounts (SMITH, 1995).

The aim of those interviews was to investigate participants' viewpoints on (1) the processes of curriculum development and enactment; (2) differences and similarities amongst curricula across PAL courses within the PAL programme; (3) pedagogical approaches; (4) pedagogical goals; and (5) pedagogical materials. The interviews were conducted in person with the PAL programme co-ordinators and via Skype with the PAL programme instructors. Data analysis, which CGT encourages to be performed during the process of data gathering, was divided into the following stages: (1) transcription of field notes and interviews at the verbatim and verbatim-with-dialect levels, respectively; (2) translation from Portuguese to English; (3) line-by-line coding through the application of constant comparison within the same interview to identify possible discrepancies in one participant's account; (4) focused coding to eliminate irrelevant codes and/or to refine initial codes; (5) theoretical coding through constant comparison across participants' accounts and between participants' perspectives and theory itself; and (6) memo-writing to compile critical reflexivity on the decisions regarding initial, focused, and theoretical codes.

The next section presents the empirically based and theoretically informed findings that emerged from data and the conclusions which were drawn from inductive, deductive, and abductive analysis of such data.

\section{Influence of Celpe-Bras on curriculum development and enactment}

The communicative nature of Celpe-Bras is connected to its developers' teaching experiences and research background/interests at the time of its conception - which had been strongly related to CLT and TBLT; moreover, the examination was created as an assessment instrument to certify proficiency of, amongst others, PEC-G students (SCARAMUCCI, 1995). When all those elements are highlighted greatly within research on PAL education, the influence of Celpe-Bras on curriculum development and enactment for PAL courses seems justifiable. The following sections present the PAL programme co-ordinators' and instructors' accounts on the development processes of PAL courses for PEC-G students in their FUs. Despite some discrepancies between co-ordinators and instructors within the same FU, general perspectives have been interpreted and divided into three main sets of findings: (1) Celpe-Bras shapes PAL curriculum due to the absence of official guidelines; (2) Celpe-Bras shapes PAL curriculum because of assumptions that it should; and (3) Celpe-Bras shapes curriculum despite assumptions that it should not. 


\section{Celpe-Bras as guidelines for curriculum development and enactment}

The common thread connecting the PAL programmes within the seven FUs where this study took place was found to be the washback effect of Celpe-Bras, since the examination, to a certain extent, was identified by all the participants - co-ordinators and instructors - as a strong influence on PAL curriculum. Such influence was considered by the participants as both positive - for focusing on the preparation of PEC-G students for the Celpe-Bras examination itself - and negative - for restricting teaching and learning opportunities to one of PEC-G students' language needs, which is, receiving their proficiency certification. The participants' perspectives regarding this issue can find support in Shohamy et al. (1996) who, as previously mentioned, argue that tests and examinations, like Celpe-Bras, potentially limit teaching and learning experiences to the development of more urgent and/or measurable language skills.

Although acknowledging the Celpe-Bras' impact, participants' viewpoints on the reasons for and extent to its influence were different and, at times, opposite - especially between groups of co-ordinators and instructors within and across PAL programmes. Those inconsistencies in accounts might have occurred due to the dissimilar understanding about participation in curriculum development and enactment that co-ordinators and instructors seemed to have. All PAL programme co-ordinators claimed to have included instructors in the decision-making processes whereas all instructors stated otherwise. For co-ordinators, participation meant to involve instructors in syllabus and material design; however, instructors felt that they could have been asked to contribute to curriculum development. Moreover, instructors did not see material design as part of curriculum enactment and, therefore, did not recognise their role as one of a decision-maker.

As discussed above, teachers' perceptions regarding their participation in and/or contribution to IPO curriculum tend to influence their sense of ownership and authorship towards it; such sense, or lack thereof, might reflect on ORA curriculum. In this particular study, it was found that differences between IPO curriculum and ORA curriculum were more noticeable when PAL programme instructors had not been, or had not perceived to have been, included in decision-making processes. The table below summarises relevant discrepancies between IPO curriculum and ORA curriculum:

Table 3 - IPO curriculum and ORA curriculum

\begin{tabular}{|cll|}
\hline FU & Co-ordinators' accounts (IPO curriculum) & \multicolumn{1}{c|}{ Instructors' accounts (ORA curriculum) } \\
\hline $01^{\text {xt }}$ & $\begin{array}{l}\text { Celpe-Bras is solely used as guidelines for } \\
\text { curriculum development due to lack of } \\
\text { further orientations }\end{array}$ & $\begin{array}{l}\text { Celpe-Bras is purposefully used as guidelines for } \\
\text { curriculum development }\end{array}$ \\
$02^{*+}$ & $\begin{array}{l}\text { Celpe-Bras is purposefully used as } \\
\text { guidelines for curriculum development }\end{array}$ & $\begin{array}{l}\text { Celpe-Bras is purposefully used as guidelines for } \\
\text { curriculum development }\end{array}$ \\
$04^{*}$ & $\begin{array}{l}\text { Celpe-Bras is purposefully used as } \\
\text { guidelines for curriculum development } \\
\text { Celpe-Bras is solely used as guidelines for } \\
\text { curriculum development due to lack of } \\
\text { further orientations }\end{array}$ & $\begin{array}{l}\text { Celpe-Bras should not be used as guidelines for } \\
\text { curriculum development } \\
\text { Celpe-Bras is solely used as guidelines for } \\
\text { curriculum development due to lack of further } \\
\text { orientations }\end{array}$
\end{tabular}




\begin{tabular}{|c|c|c|}
\hline $05^{*+}$ & $\begin{array}{l}\text { Celpe-Bras should not be used as } \\
\text { guidelines for curriculum development }\end{array}$ & $\begin{array}{l}\text { Celpe-Bras is purposefully used as guidelines for } \\
\text { curriculum development }\end{array}$ \\
\hline $06^{x+}$ & $\begin{array}{l}\text { Celpe-Bras is purposefully used as } \\
\text { guidelines for curriculum development }\end{array}$ & $\begin{array}{l}\text { Celpe-Bras is purposefully used as guidelines for } \\
\text { curriculum development }\end{array}$ \\
\hline $07^{*+}$ & $\begin{array}{l}\text { Celpe-Bras is solely used as guidelines for } \\
\text { curriculum development due to lack of } \\
\text { further orientations }\end{array}$ & $\begin{array}{l}\text { Celpe-Bras is purposefully used as guidelines for } \\
\text { curriculum development }\end{array}$ \\
\hline
\end{tabular}

Source: adapted from Carilo (2018).

FUs 01, 03, and 06 (marked with an " $x$ ") are those which were represented by PAL programme co-ordinators who claimed that PAL programme instructors had not participated in curriculum development; however, they had been involved in curriculum enactment especially materials design. FUs 02, 04, 05, and 07 (marked with an “*”) are those represented by PAL co-ordinators who claimed that PAL programme instructors had been involved in the curriculum development processes. FUs 01, 02, 03, 05, 06, and 07 (marked with a " + ") are those represented by PAL programme instructors who stated that they had not participated in decision-making processes during curriculum development. Findings clearly show that instructors who perceived to have contributed to curriculum development seemed to have aligned their practice, or enactment, to IPO curriculum. In that sense, IPO curriculum and ORA curriculum presented less discrepancies between each other. Nevertheless, instructors who perceived not to have participated in curriculum development aligned their practice to their own teaching experience, background, and/or familiar approaches.

The co-ordinator-instructor dynamics within FU05 exemplify how extreme the gap between IPO curriculum and ORA curriculum might be when teachers are excluded from decision-making processes. PAL programme co-ordinator with FU05 argued that Celpe-Bras should not be used as guidelines for curriculum development whereas instructors stated the complete opposite. PAL programme instructors with FU05 stated that they were not familiar with the theoretical and pedagogical approaches on which the co-ordinator wanted them to base their practice; thus, they relied on what they considered familiar. Hence, the communicative- and task-based nature of Celpe-Bras served as guidelines for curriculum development (mostly, both IPO and ORA) across the seven FUs.

The importance of Celpe-Bras and its relevance for the PAL field are not being questioned in this article; however, using the CLT- and TBLT-based theoretical assumptions informing Celpe-Bras as guidelines for curriculum development has advanced outdated pedagogies related to language teaching and learning. The following section summarises the findings that emerged from this study regarding the extent to which those outdated theoretical and pedagogical perspectives influence three key elements of educational practice: syllabus, materials, and assessment.

\section{Celpe-Bras as guidelines for syllabus design, pedagogical materials, and assessment}

The abstract nature of curriculum might contribute to the perception that syllabus, materials, and assessment are more concrete elements within pedagogical practices - 
concrete here parallels applicability for practitioners and visibility for learners. Although CLT and TBLT approaches do not offer a formula through which additional language education should be managed, their frameworks provide practitioners with straightforward procedures and methods for pedagogical purposes. Furthermore, definitions of language and language use, competence, and culture that should be prioritised are widely promoted; hence, syllabus, materials, and assessment instruments are designed to reflect those notions.

Findings evidenced that the idealised notion of "the native speaker" has been extensively portrayed as a model of authenticity in the investigated contexts. Syllabus, materials, and assessment instruments were claimed to have presented, as well as promoted, language homogeneity amongst diverse individuals sharing one speech community - the Brazilian speech community - which, despite being linguistically diverse, it is commonly represented by dominant classes from Rio de Janeiro and/or São Paulo (see LIMA, 2008). In that sense, language authenticity is based on a standardised monolingual native speaker; consequently, when language use follows sociocultural and linguistic patterns that mimic such speaker, user's competence can be granted the status of proficient.

Culture, in turn, was claimed to have been part of PAL teaching and learning background for comparison purposes. Findings revealed that materials rarely address cultural issues in a way other than by requiring students to compare "the Brazilian culture" with "the culture of their country(ies)." Through that essentialist lens, culture seemed to have been perceived and promoted as a set of social behaviours, beliefs, viewpoints, and attitudes that are commonly and homogeneously exercised by those who share a nationality rather than built through personal and societal, historical, linguistic, ethnic, racial, and gender-related experiences. This process of disregarding cultural diversity within while emphasising differences across speech and/or geographic communities enables (re)production of cultural stereotypes and prioritisation of dominant classes' cultures.

Instructors' accounts showed that syllabus had been designed in a manner that reflected a progression of linguistic resources and discourse genres from which PEC-G students would have to draw in order to comprehend and produce language to complete Celpe-Bras-like communicative tasks. For that purpose, selected and/or developed pedagogical materials aligned to written and oral comprehension and production of communicative tasks that can be found in Celpe-Bras examinations. Furthermore, assessment instruments had been mainly built with tasks retrieved from prior Celpe-Bras examinations although, some instructors had adjusted and/or reviewed such tasks. In other words, anything that had been deemed unnecessary for the completion of in-class Celpe-Bras-like communicative tasks, course-related assessment(s), and the Celpe-Bras examination itself was disregarded by instructors and omitted from syllabus, materials, and assessment instruments.

Considering that notions of language and language use, competence, and culture, on which syllabus, materials, and assessment instruments were based for the development of ORA curriculum are those informing the Celpe-Bras examination within all the seven PAL programmes investigated, it is possible to argue that Celpe-Bras shapes syllabuses, materials, 
and assessment instruments for PAL courses for PEC-G students. In addition, passing the Celpe-Bras examination - which, as mentioned previously, is a requirement for further participation in PEC-G - has been seen as linguistic competence since it determines one's level of proficiency through measurement of their success in conveying identifiable and transferable skills while performing communicative tasks. Ultimately, PAL students, especially those participating in PEC-G, appeared to have had their role in the learning process reduced to potential Celpe-Bras examinees.

\section{A theoretical and pedagogical shift for Portuguese as an Additional Language}

Given that PEC-G students, after passing the Celpe-Bras examination become undergraduate students at a FU in Brazil, their language needs which are not related to the examination itself should be considered. CLT and TBLT approaches do not seem to be informed by theoretical and/or pedagogical perspectives which encourage advancement or flexibility of notions of language and language use, competence, and culture with the purpose to expand citizenship and social agency (GUILHERME; DIETZ, 2015). As previously addressed, critical intercultural language pedagogies aim to further individuals' critical thinking, selfreflexivity, transformative and liberating social agency, and citizenship by disrupting power relations, starting with the teacher-student dynamics, through teaching and learning processes as dialectical and dialogical (re)production of knowledge. In order to move PAL education from communicative approaches towards critical intercultural pedagogies, those key notions - language and language use, competence, and culture - that are presented and promoted in syllabus, materials, and assessment instruments need to be revisited.

The notion of language currently informing PAL education goes beyond language as a system, it does not reject it completely; thus, there is a need for a reconceptualisation of language. The reconceptualisation proposed by Liddicoat and Scarino (2013) positions language away from grammar- and lexicon-based communication through language use. Their proposal, within critical intercultural language pedagogies, echoes that of Kramsch (2009), who defines language as a symbolic system through which one apprehends and interprets oneself and the world. Using additional languages, in turn, means accessing alternative (re)signifying practices to apprehend and interpret oneself and others, one's worlds and those of others through different sets of sociocultural, historical, linguistic lenses. Within PAL contexts, language and language use would have to cease being presented as both the manifestation and the representation of certain classes of native speakers. Conversely, critical intercultural notions of language and language use would enable PAL students to exercise their symbolic power, that is, a declarative and performative power that allows additional language students to (re)present and (re)create multiple realities in multiple varieties of Portuguese. For example, PAL students who identify themselves as non-binary should be able to learn non-binary adjectives and pronouns in Portuguese - even though such terms are not part of standardised Portuguese which can be found in textbooks and Celpe-Bras-like tasks.

By updating the notion of language and language use, competence also secures new 
understanding. Instead of basing one's competence on the development of recognisable and transferable language skills which must be used to achieve consensus during a process of meaning-making, critical intercultural language pedagogies do not equate competence as the ability to even out differences through interactions and negotiations. On the contrary, critical intercultural competence, or symbolic competence, enables (re)framing one's perspectives on (un)familiar sociocultural contexts with the purpose of acting upon them, changing them, and/or creating alternatives to them in a collaborative, yet critical, manner. Competence, according to this understanding, cannot be measured through one's ability to emulate certain native speakers and mimic their sociocultural stances in interactions; rather, it enables multiple viewpoints to be expressed, addressed, clarified, negotiated, understood, and, ideally, respected without, necessarily, achieving any sort of consensual conclusion.

Just as individuals' diverse backgrounds influence their language use and competence, one's cultures also play an important role in additional language use. By decoupling notions of culture and nationality - which is not common in CLT and TBLT approaches, PAL students would be able to (re)shape their cultures and move them away from stereotypes and homogenised perceptions. Critical intercultural understanding moves away from an essentialist uniformity process towards a dynamic meaning-making process, focusing on the interaction itself, which needs to be based on individuals' interpretations and sociocultural historical stances. In that sense, PAL students would be able to expand their sociocultural, historic, linguistic, ethnic, gender-related, racial, religious, individual, and societal frameworks in order to comprehend their own stances and those of others. The dynamism nature that critical intercultural language pedagogies attribute to culture aims to challenge naturalisation and ideologically-charged portrayals of cultures - which can be easily accepted as true due to the way they might be officially presented and/or promoted (e.g., textbooks, proficiency examinations, teachers' accounts).

Further implications of a theoretical and pedagogical shift within PAL education would include (1) guidelines for curriculum development and enactment; and (2) teacher development and teacher education. Guidelines for curriculum would have to focus on flexibility, contextualisation, democratisation, and overall sociocultural and linguistic problematisation to surpass the dimension of syllabus, materials, and assessment. PAL curriculum would allow education for cosmopolitan citizenship to be promoted and for change through social agency to be encouraged. By enabling multicultural and multilingual identities to be identified, addressed, and expressed, critical intercultural PAL curriculum could influence the development of individual and/or collective emancipation through additional language ownership. This political/ideological dimension within PAL curriculum would require engagement - which is not necessarily explicitly foregrounded by communicative approaches - from all of those involved in learning and teaching.

For PAL teachers to be (more) politically engaged, PAL teacher education programmes would have to be prepared to offer modules on critical intercultural language pedagogies. Furthermore, practice would have to allow pre-service and/or in-service PAL teachers to become familiarised with multilingual and multicultural contexts. Specific abilities and skills 
for critical intercultural teaching - such as interpretation, analysis evaluation of diverse viewpoints - would have to be prioritised by PAL teacher education programmes. PAL teachers would have to introduce critical intercultural learning to PAL students whose additional language learning background would, most likely, be related to communicative and/or grammar-based approaches. PAL education, in that sense, would entail identity (re)building, active and critical participation, multiple literacy, and meaning making. Additionally, PAL teachers would be encouraged to position themselves within the discussed issues since neutrality does not contribute to the (re)negotiation of sociocultural stances and political positions. Critical intercultural language education might impose theoretical and pedagogical challenges for PAL teachers since new knowledges would have to be acquired and different perspectives would have to be (re)considered. Nevertheless, adopting critical intercultural language pedagogies might equip PAL teachers to advance PAL education, to broaden its purposes, and, especially, to empower PAL students.

\section{References}

APPLE, Michael W. Curriculum planning: content, form, and the politics of accountability. In: CONNELLY, F. Michael; HE, Ming Fang; PHILLION, JoAnn (Eds). The SAGE Handbook of Curriculum and Instruction. Thousand Oaks: SAGE, 2008. p. 25-44. https://doi.org/10.4135/9781412976572.n2

BACHMAN, Lyle F. Fundamental considerations in language testing. Oxford: Oxford University Press, 1990.

BARNETT, Ronald. Supercomplexity and the curriculum. Studies in Higher Education, London, v. 25, n. 3, p. 225-265, 2000. https://doi.org/10.1080/713696156

BASCIA, Nina; CARR-HARRIS, Shasta; FINE-MEYER, Rose; ZURZOLO, Cara. Teachers, curriculum innovation, and policy formation. Curriculum inquiry, London, v. 44, n. 2, p. 228-248, 2014. https://doi.org/10.1111/curi.12044

BREEN, Michael P. Authenticity in the foreign language classroom. Applied Linguistics, Oxford, v. 6, n. 1, p. 62-70, 1989. https://doi.org/10.1093/applin/6.1.60

BYRAM, Michael. Language awareness and (critical) cultural awareness - relationships, comparisons, and contrasts. Language Awareness, London, v. 21, n. 1-2, p. 5-13, 2012. https://doi.org/10.1080/09658416.2011.639887

CANALE, Germán. (Re)Searching culture in foreign language textbooks, or the politics of hide and seek. Language, Culture and Curriculum, London, v. 29, n. 2, p. 225-243, 2016. https://doi.org/10.1080/07908318.2016.1144764

CANALE, Michael. From communicative competence to communicative language pedagogy. In: RICHARDS, Jack C.; SCHMIDT, Richard W. (Eds). Language and Communication. Abingdon: Routledge, 1983. p. 2-16.

CANALE, Michael; SWAIN, Merrill. Theoretical bases of communicative approaches to second language teaching and testing. Applied Linguistics, Oxford, v. 1, n. 1, p. 1-47, 1980. https://doi.org/10.1093/applin/1.1.1 
CARILO, Michele Saraiva. Portuguese as a foreign language within the context of the exchange programme for undergraduate students in Brazil: a proposal for language-in-education policy and curriculum guidelines informed by critical and intercultural perspectives. Tese (Doutorado em Educação de Línguas Modernas) - Programa de Pós-graduação em Educação, Moray House School of Education, The University of Edinburgh, Edinburgh, UK, 2018.

CHARMAZ, Kathy. Constructing Grounded Theory. London: SAGE, 2014.

CROZET, Chantal. The Intercultural Foreign Language Teacher: challenges and choices. In: DASLI, Maria.; DÍAZ, Adriana R. (Eds). The critical turn in language and intercultural communication pedagogy. London: Routledge, 2017. p. 143-161.

EISNER, Elliot W. A development agenda: creative curriculum development and practice. Journal of Curriculum and Supervision, Alexandria, v. 6, n. 1, p. 62-73, 1990.

FORMAN, Ross. How local teachers respond to the culture and language of a global English as a Foreign Language textbook. Language, Culture and Curriculum, London, v. 27, n. 1, p. 72-88, 2014. https://doi.org/10.1080/07908318.2013.868473

FREIRE, Paulo. Pedagogia do Oprimido. Rio de Janeiro: Paz e Terra, 1987.

FULLAN, Michael. Curriculum implementation and sustainability. In: CONNELLY, F. Michael; HE, Ming Fang; PHILLION, JoAnn (Eds). The SAGE Handbook of Curriculum and Instruction. Thousand Oaks: SAGE, 2008. p. 113-122. https://doi.org/10.4135/9781412976572.n6

GANDANA, Isti; PARR, Graham. Professional identity, curriculum and teaching intercultural communication: an Indonesian case study. Language, Culture and Curriculum, London, v. 26, n. 3, p. 229-246, 2013. https://doi.org/10.1080/07908318.2013.833620

GRAY, John. The construction of English culture, consumerism, and promotion in the ELT global coursebook. Basingstoke: Palgrave Macmillan, 2010.

GUILHERME, Maria Manuela. Critical Language and Intercultural Communication Pedagogy. In: JACKSON, Jane. (Ed.). The Routledge Handbook of Language and Intercultural Communication. Abingdon: Routledge, 2012. p. 357-371.

GUILHERME, Maria Manuela.; DIETZ, Gunther. Difference in diversity: multiple perspectives on multicultural, intercultural, and transcultural conceptual complexities. Journal of Multicultural Discourses, London, v. 10, n. 1, p. 1-21, 2015. https://doi.org/10.1080/17447143.2015.1015539

HALLIDAY, Michael A.K. Explorations in the functions of language. London: Edward Arnold, 1973.

HOLLIDAY, Adrian. Culture, communication, context, and power. In: JACKSON, Jane (Ed). The Routledge Handbook of Language and Intercultural Communication. Abingdon: Routledge, 2012. p. 37-51.

HYMES, Dell H. On communicative competence. In: PRIDE, John B.; HOLMES, Janet. (Eds). Sociolinguistics: Selected Readings. Harmondsworth: Penguin, 1971. p. 269-293.

JOHNSON, John M. In-depth Interviewing. In: GUBRIUM, Jaber F.; HOLSTEIN, James. (Eds). The SAGE Handbook of Interview Research. London: SAGE, 2001. p. 695-711.

KACHRU, Braj B. World Englishes: critical concepts in Linguistics. New York: Routledge, 2006. 
KVALE, Steinar. Doing Interviews. London: SAGE, 2007. https://doi.org/10.4135/9781849208963

KELLY, Albert V. The Curriculum: theory and practice. London: SAGE, 2009.

KENNEDY, Claire; DÍAZ, Adriana R.; DASLI, Maria. Cosmopolitan meets language education. In: DASLI, Maria.; DÍAZ, Adriana R. (Eds). The critical turn in language and intercultural communication pedagogy. London: Routledge, 2017. p. 162-179.

KRAMSCH, Claire. Post 9/11: foreign languages between knowledge and power. Applied Linguistics, Oxford, v. 26, n. 4, p. 545-567, 2005. https://doi.org/10.1093/applin/ami026

KRAMSCH, Claire. The symbolic dimensions of the intercultural. Language Teaching, Cambridge, v. 44, n. 3, p. 354-367, 2011. https://doi.org/10.1017/S0261444810000431

KRAMSCH, Claire. Teaching foreign languages in an era of globalisation: introduction. Modern Language Journal, New York, v. 98, n. 1, p. 296-311, 2014. https://doi.org/10.1111/j.1540$\underline{4781.2014 .12057 . x}$

LIDDICOAT, Anthony J.; SCARINO, Angela. Intercultural Language Teaching and Learning. Oxford: Wiley-Blackwell, 2013. https://doi.org/10.1002/9781118482070

LIMA, Ronaldo A. Representações do Brasil em textos do exame Celpe-Bras. Tese (Doutorado em Estudos da Linguagem) - Programa de Pós-Graduação em Letras, Universidade Federal Fluminense, Niterói/RJ, 2008.

MARSH, Colin. Key concepts for understanding curriculum. London: RoutledgeFalmer, 2004. https://doi.org/10.4324/9780203326893

MICKAN, Peter. Language curriculum design and socialisation. Bristol: Multilingual Matters, 2013. https://doi.org/10.21832/9781847698315

NATION, Paul; MACALISTER, John. Language curriculum design. London: Routledge, 2010. https://doi.org/10.4324/9780203870730

NUNAN, David. Communicative tasks and the language curriculum. TESOL Quarterly, New York, v. 25, n. 2, p. 279-295, 1991. https://doi.org/10.2307/3587464

NUNAN, David. Task-based language teaching. Cambridge: Cambridge University Press, 2004. https://doi.org/10.1017/CBO9780511667336

RICHARDS, Jack C. Course planning and syllabus design. In: RICHARDS, Jack C. (Eds). Curriculum development in language teaching. 2. ed. Cambridge: Cambridge University Press, 2017. p. 145-197.

SCARAMUCCI, Matilde R. V. O projeto Celpe-Bras no âmbito do Mercosul: contribuições para uma definição de proficiência comunicativa. In: ALMEIDA FILHO, José Carlos P. (Eds). Português para Estrangeiros: interface com o espanhol. Campinas: Pontes Editores, 1995. p. 77-90.

SCARAMUCCI, Matilde R. V. Proficiência em LE: considerações terminológicas e conceituais. Trabalhos em Linguística Aplicada, Campinas, v. 36, n. 2, p. 11-22, 2000.

SCARAMUCCI, Matilde R. V. Efeito retroativo da avaliação no ensino/aprendizagem de línguas: o estado da arte. Trabalhos em Linguística Aplicada, Campinas, v. 43, n. 2, p. 203-226, 2004. https://doi.org/10.1590/S0103-18132004000200002 
SCARAMUCCI, Matilde R. V. O exame Celpe-Bras e a proficiência do professor de português para falantes de outras línguas. Digilenguas, Córdoba, v. 12, n. junho, p. 48-67, 2012.

SCHLATTER, M. SCARAMUCCI, Matilde V. R.; PRATI, S. ACUÑA, L. Celpe-Bras e CELU: impactos da construção de parâmetros comuns de avaliação em proficiência em português e espanhol. In: ZOPPI-FONTANA, M. (Ed). O português do Brasil como língua transnacional. Campinas: RG Editora, 2009. p. 195-222.

SCHOFFEN, Juliana. R. Gêneros do discurso e parâmetros de avaliação de proficiência em português como língua estrangeira no exame Celpe-Bras. Tese (Doutorado em Linguística Aplicada) - Programa de Pós-Graduação em Letras, Universidade Federal do Rio Grande do Sul, Porto Alegre/RS, 2009.

SHOHAMY, Eleana; DONITSA-SCHMIDT, Smadar; FERMAN, Irit. Test impact revisited: washback effect over time. Language Testing, London, v. 13, p. 298-317, 1996. https://doi.org/10.1177/026553229601300305

SMITH, Jonathan A. Semi-structured Interviewing and Qualitative Analysis. In: SMITH, Jonathan A.; HARRE, Rom; VAN LANGENHOVE, Luk. (Eds). Rethinking Methods in Psychology. London: SAGE, 1995. p. 10-27. https://doi.org/10.4135/9781446221792.n2

ZOPPI-FONTANA, Mónica G.; DINIZ, Leandro R. A. Declinando a língua pelas injunções do mercado: institucionalização do português língua estrangeira (PLE). Estudos Linguísticos, São Paulo, v. 37, n. 3, p. 89-119, 2008. 